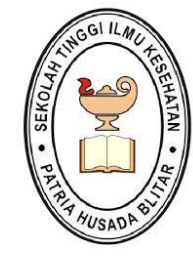

JCSH

JOURNAL OF COMMUNITY SERVICE

FOR HEALTH

http://juda.phb.ac.id/index.php/jcsh

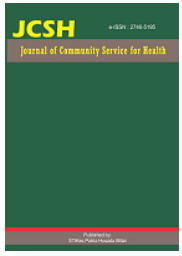

\title{
Non-Pharmacological Management of Pruritus in Chronic Kidney Disease Patients at Panti Waluya Sawahan Hospital
}

\author{
Pertiwi Perwiraningtyas ${ }^{1}$, Ani Sutriningsih ${ }^{2}$, Wahyu Dini Metrikayanto ${ }^{3}$ \\ ${ }^{1,2,3}$ Department of Nursing, Tribhuwana Tunggadewi University Malang, Indonesia
}

\begin{tabular}{l} 
Article Information \\
\hline History Article: \\
Received, 29/07/2021 \\
Accepted, 13/10/2021 \\
Published, 05/11/2021
\end{tabular}

Keywords:

Chronic Kidney Disease,

Non Pharmacological,

Pruritus

\begin{abstract}
Patients of chronic kidney disease require long-term hemodialysis therapy. However, this therapy has various complications, one of which is pruritus. Pruritus can interfere with individual activities, cause sleep disturbances, lesions and hyperpigmentation on the skin, to impact the patient's quality of life. So that non-pharmacological management is needed to treat pruritus. The design was cross sectional. The population in this community service was chronic kidney failure patients undergoing hemodialysis therapy in the hemodialysis room. The sample was patients who experience pruritus and undergo hemodialysis therapy at least $1 \mathrm{x} /$ week as many as 45 people. The variables were health education related to non-pharmacological management and pruritus. The instruments used leaflets and counseling program units for health education, while for pruritus used the Numeric Rating Scale. The average patient experienced pruritus on a scale of 5, which was a moderate category where itching was felt by frequent scratching. After health education, patients understand how to deal with pruritus with non-pharmacological methods so that the patient's quality of life becomes better.
\end{abstract}

(C) 2021 Journal of Community Service for Health

Correspondence Address:

Tribhuwana Tunggadewi University Malang - East Java, Indonesia

E-ISSN : 2746-5195

Email: perwiraningtyas@gmail.com

DOI: 10.26699/jcsh.v2i2.ART.p038-041

This is an Open Access article under the CC BY-SA license (http://creativecommons.org/licenses/by-sa/4.0/) 


\section{INTRODUCTION}

Chronic Kidney Disease is a failure of kidney function to maintain metabolism and fluid and electrolyte balance due to progressive destruction of kidney structures with manifestations of accumulation of residual metabolites (uremic toxic) in the blood (Muttaqin, Arif, 2012). The therapy or treatment that can be given to patients with end-stage renal failure is hemodialysis. Hemodialysis is a procedure for cleaning blood through an artificial kidney or dialyzer and assisted in its implementation by a machine (Rahman, M., Kaunang, T., \& Elim, 2016). This treatment is expected to improve the quality of life and prolong the life of patients with chronic kidney failure (Rahman, Kaunang, and Elim, 2016).

Chronic kidney failure patients require longterm hemodialysis therapy (Smeltzer \& Bare, 2002). Most patients with kidney failure require 12 to 15 hours of hemodialysis per week which is divided into 2 or 3 sessions where each session lasts between 3 to 6 hours. Hemodialysis activities will continue throughout his life (Widyantara, 2016). Patients require long-term dialysis therapy, which is necessary to maintain survival and control symptoms of uremia (Smeltzer, 2002). However, dialysis therapy itself has various complications, one of which is pruritus that occurs during dialysis when the end products of metabolism leave the skin (Smeltzer, 2002).

Everyone perceives uremic pruritus differently. When pruritus is treated late, it can interfere with individual activities, cause sleep disturbances if it occurs at night, cause lesions and hyperpigmentation on the skin, and have an impact on the patient's quality of life. Based on the results of the preliminary study, it was found that from early September 2019 to November 2020, of 1107 kidney failure patients undergoing hemodialysis therapy at Panti Waluya Sawahan Hospital, Malang, 250 of them complained of experiencing pruritus. Thus, to overcome this, non-pharmacological management is needed in order to reduce the pruritus experienced by CKD patients undergoing hemodialysis therapy.

\section{METHOD}

The design was cross sectional. The population in this community service was CKD patients who undergo hemodialysis therapy in the hemodialysis room. The sample was part of the population that meets the inclusion criteria, such as those who experienced pruritus and underwent hemodialysis therapy at least once a week. The variables were health education related to nonpharmacological management and pruritus. The instruments used leaflets and SAP for health education, while for pruritus used the Numeric Rating Scale.

The activity was carried out for one day on Thursday, November 19, 2020 in the Hemodialysis Room of Panti Waluya Hospital Malang. CKD patients were given material related to non-pharmacological management to treat pruritus in CKD patients undergoing hemodialysis therapy. The activity was supported by leaflets on the topic of pruritus and non-pharmacological measures to reduce pruritus in CKD patients, so that participants can more easily understand and provide provisions for the management of pruritus at home. At the final stage, an evaluation was carried out by means of discussion and asking questions according to the topics that have been described.

\section{RESULTS}

Table 1. Distribution table for gender and age of respondents

\begin{tabular}{lll}
\hline Characteristics & F & $\boldsymbol{\%}$ \\
\hline Gender & & \\
$\quad$ Male & 23 & 51 \\
$\quad$ Female & 22 & 49 \\
\hline Age & & \\
28-48 years & 18 & 40 \\
49-59 years & 14 & 31 \\
60-72 years & 13 & 29 \\
\hline Souce: Primary Data & &
\end{tabular}

Based on Table 1, it was found that more than half of the respondents who underwent hemodialysis therapy were male $(51 \%)$ and almost half of the respondents were aged 28 to 48 years (40\%).

Table 2. Pruritus scale

\begin{tabular}{cccc}
\hline Variable & Mean & Median & Modus \\
\hline Pruritus scale & 5.18 & 5.00 & 5 \\
\hline
\end{tabular}

Based on Table 2, the average pruritus scale of patients undergoing hemodialysis is 5.18 (medium category), the median and mode values are 5 (medium category).

\section{DISCUSSION}

Based on Table 2, the average pruritus scale of patients undergoing hemodialysis is 5.18 (medium category), the median and mode values are 5 (medium category). The average patient experience pruritus with medium category indicated by itching accompanied by frequent scratching. Complaints of pruritus are influenced by hemodialysis measures carried out by the 
patient for a long period of time, so that it can cause itching and often scratch the skin. Pruritus is the result of increased urea in the blood (uremic pruritus). The patient complains of this situation appearing intermittently even at any time in several parts or throughout the body. This result in disruption of the patient's activities and the occurrence of sleep disturbances, thus indirectly affecting the patient's quality of life (Chen et al., 2013). Chronic kidney disease patients undergoing hemodialysis therapy experience various complications including air embolism, hypotension, chest pain, balance disorders, nausea and vomiting, muscle cramps, increased blood urea levels, and pruritus (Smeltzer, Suzanne C., Bare, 2010).

In several studies it was found that gender factors affect the occurrence of pruritus. More than half of the respondents are male. Research conducted by Sembiring, Nasution and Ariani (2020), the majority of males experience uremic pruritus compared to females where gender has been associated with the pathogenesis of uremic pruritus (Berger \& Steinhoff, 2011; Lin et al. 2011; Combs et al. 2015; Aval et al. 2018, in (Sembiring, Friska; Nasution, Siti Saidah; Ariani, 2020). Based on the results of the study, men and women differ in how they perceive pruritus. Women in general feel pruritus more often. This is indicated by scratching behavior that is more frequent. In addition, the psychological disorders experienced are also more severe. The itching experienced by women is more like a burning sensation, indicating a stronger neuropathic component and a higher intensity of itching in the lower extremities. However, for men, itching is usually experienced in the upper extremities (Stumpf and Pfleiderer, et al, 2016).

As for age, almost half of the respondents are 28-48 years old. The age of the respondent also affects the appearance of pruritus. According to Riza (2012) and Bianti (2016), the relationship between age and pruritus is due to the fact that the older a person is, the drier their skin condition will be and the higher the incidence and severity of xerosis. According to researchers conducted by Astuti and Husna (2017), the results showed that at the age of 41-60 years, the patient had entered the stage of advancing to the elderly, where the patient experienced various organ problems, such as decreased kidney function, or skin problems. The skin will become dry (xerosis) . In addition, patients who experience chronic kidney failure problems, metabolism of phosphorus, calcium, and magnesium so that the occurrence of uremia which exacerbates the emergence of pruritus problems. Pruritus is common in elderly patients. In a 2010 study of 4099 geriatric patients in Turkey, pruritus was among the five most common diseases and was often associated with dry skin.
The incidence and severity of dry skin was increased by age (Bianti, 2016) .

Hemodialysis therapy is one of the things that aggravate the occurrence of pruritus, so that it can cause itching. Pruritus can be felt on the back, feet, hands and all over the body. The itching that is felt can be red and cause red spots to cause scars. According to Wulandari's research (2019) regarding the long-term relationship between hemodialysis and the incidence of uremic pruritus in patients with chronic renal failure, it was stated that the incidence of uremic pruritus could be identified from the appearance of garal complaints, uremic occurrence (urea levels > 50 $\mathrm{mg} / \mathrm{dl}$ ), uremic syndrome and dry skin. The complaints of itching felt by respondents on the feet, hands, buttocks and back.

\section{CONCLUSION}

The average score of patient with chronic kidney failure at Panti Waluya Hospital, Malang who experienced pruritus was on a scale of 5 , which was in the moderate category where itching was felt by frequent scratching.

\section{SUGGESTION}

This activity is expected to increase knowledge of non-pharmacological management of pruritus in CKD patients. Thus, it can reduce the scale of pruritus experienced which has an impact on the fulfillment of optimal sleep and activity as well as improving the quality of life of CKD patients.

\section{REFFERENCES}

Astuti, Rini dan Husna, C. (2017) 'Pruritus pada Pasien Gagal Ginjal Kronik', Jurnal Ilmiah Mahasiswa Keperawatan, 4(2).

Bianti, M. (2016) 'Kulit Kering pada Usia Lanjut', CDK-245, 43(10).

Chen, H. et al. (2013) 'Uremic Pruritus, Dialysis Adequacy, and Metabolic Profiles in Hemodialysis Uremic Pruritus, Dialysis Adequacy, and Metabolic Profiles in Hemodialysis Patients: A Prospective 5Year Cohort Study', (January 2014). doi: 10.1371/journal.pone.0071404.

Kandou (2016) 'Hubungan antara lama menjalani hemodialisis dengan kualitas hidup pasien yang menjalani hemodialisis di Unit Hemodialisis', 4.

Ko, M. J., Wu, H. Y., Chen, H.Y., Chiu, Y. L., Hsu, S. P., Pai, M. F., et al (2013) 'Uremic Pruritus, Dialysis Adequancy, And Metabolic Profiles In Hemodialysis Patients: A Prospective 5-Year Cohort Study', Plos ONE, 8(8).

Muttaqin, Arif, K. S. (2012) Askep Gangguan Sistem Perkemihan. Jakarta: Salemba 
Medika.

Rahman, M., Kaunang, T., \& Elim, C. (2016) 'Hubungan antara lama menjalanihemodialisis dengan kualitas hidup pasien yang menjalani hemodialisis di Unit Hemodialisis RSUP Prof. Dr. RD Kandou Manado', e-CliniC, 4(1).

Riza, D. N. (2012) Prevalensi dan Derajat Terjadinya Pruritus pada Pasien Hemodialisis di RSUP H. Adam Malik Medan. Universitas Sumatera Utara.

Sembiring, Friska; Nasution, Siti Saidah; Ariani, Y. (2020) 'Gambaran Pruritus Uremik Pasien Gagal Ginjal Kronik Di Unit Hemodialisa Rumah Sakit Umum Pustaka Haji Adam Malik Medan', Jurnal perawat Indonesia, 4(1), pp. 1-7.

Smeltzer, Suzanne C., Bare, B. (2010) Buku Ajar Keperawatan Medikal-Bedah Brunner \& Suddarth. Jakarta: EGC.

Smeltzer \& Bare (2002) Buku Ajar Keperawatan Medikal-Bedah Brunner \& Suddarth. Jakarta: EGC.

Stumpf, Astrid., Pfleiderer, B. (2016) Sex and Gender Specific Differences in Chronic Pruritus. Munster: ResearchGate. Available at: https://link.springer.com/chapter/10.1007/9 78-3-319-33142-3_16.

Widyantara, I. F. eka (2016) Analisis FaktorFaktor yang Behubungan Dengan Kejadian Gagal Ginjal Kronik Pada Pasien Hemodialisis Di RSUD Tugurejo Semarang. Universitas Muhammadiyah Semarang.

Wulandari, E. (2019) 'Hubungan Lama Hemodialisa dengan Kejadian Pruritus Uremi pada pasien Gagal Ginjal Kronis Rsud Dr. Rahdjono Ponorogo', Jurnal Kesehatan Manarang, 5(1). 